\title{
Санкт-Петербург как город-символ
}

\author{
Г.В.Мазаев, УралНИИпроект, Екатеринбург
}

В статье предложена версия о разработке Ж.-Б. Леблоном плана Санкт-Петербурга 1717 года как города-символа, выражающего сакральные идеи и символику «спекулятивного масонства» начала XVIII века. Версия основана на предположении о членстве в масонских ложах как Леблона, так и самого императора Петра I. Показана краткая история раннего «оперативного» масонства, развивавшегося в Европе начиная с X века и являвшегося объединениями-гильдиями строителей, к XVI веку давшего несколько направлений деятельности, в том числе «спекулятивного масонства» как моральной теории о строительстве идеального человеческого общества. Версия о членстве Петра I в масонской ложе шотландского обряда Андрея Первозванного подкреплена анализом архитектурных предпочтений Петра I, соответствующих традициям этой ложи. Предложена версия деятельности Леблона в Санкт-Петербурге с точки зрения его вероятно членства в масонской ложе. Показано градостроительное воплощение в плане СанктПетербурга масонской символики и вероятного масонского статуса самого Петра I.

Ключевые слова: символы в градостроительстве, символика масонства, история раннего масонства, город-символ.

\section{St. Petersburg as a Symbol City}

\section{G.V.Mazaev, UralNIIproekt, Ekaterinburg}

The article proposes a version concerning the development of J.-B. Leblon's plan of St. Petersburg in 1717 as a symbol city expressing sacred ideas and symbols of "speculative Freemasonry" of the beginning of the XVIII century. The version is based on the assumption of membership in the Masoniclodges of both Leblond and Emperor Peter I himself. A brief history of the early "operational" Freemasonry, which developed in Europe since the $X$ century and was a guild association of builders, which by the 16 th century gave several directions of activity, is shown including "speculative Freemasonry" as a moral theory about the construction of an ideal human society. The version of the membership of Peter I in the Masoniclodge of the Scottish rite of St. Andrew the First-Called is supported by an analysis of the architectural preferences of Peter I, corresponding to the traditions of this lodge. A version of Leblon's activity in St. Petersburg is proposed in terms of his likely membership in thatlodge. The town-planning embodiment in terms of St. Petersburg of Masonic symbolism and thelikely Masonic status of Peter the Great is shown.
Keywords: symbols in urban planning, the symbolism of Freemasonry, the history of early Freemasonry, the city-symbol.

Жизнь и работа архитектора Жана Батиста Леблона в России полна удивительных фактов, событий и загадок. Будучи одним из многих наёмных архитекторов, не имея опыта градостроительства и знания российских условий, он по неясным причинам получал необычайно высокую оплату своего труда, звание «генерал-архитектора» с широкими полномочиями. Леблон был сразу представлен Петру I, с которым провёл в беседах несколько дней и получил от него самые лестные характеристики. Мало что сделав практически, он остался в числе выдающихся зодчих в истории северной столицы. Какова причина всего этого? Изучая работы историков архитектуры, посвящённые Леблону, нельзя найти ответ на этот вопрос. Проект плана Петербурга, выполненный Леблоном, собрал множество негативных оценок, которые показывают его автора по меньшей мере беспомощным дилетантом. Но почему именно Леблон получил возможность его разрабатывать, что за город предложил Петру I этот «архитектор-диковинка» и почему он получил такую характеристику от самого Петра? Понять причины удивительного взлёта Леблона, столь же быстрого его падения и ухода из жизни, опираясь на одни традиционные исследования, невозможно. Мы попробуем выдвинуть и обосновать новую гипотезу о работе Леблона в России, спорную, но способную объяснить многие события.

$* * *$

Кандидатуру Леблона как замену умершему в 1714 году «баудиректору» Петербурга архитектору Шлютеру предложил русский агент в Париже, племянник ближайшего друга Петра I Франца Лефорта - Иван Исаевич Лефорт. Он приехал в Париж в сентябре 1715 года, чтобы нанимать мастеров для работы в России. Пётр I поручил комиссару адмиралтейства Конону Никитичу Зотову проверить рекомендацию Лефорта. Зотов докладывал Петру I о Леблоне: «знает архитектуру, сады, церкви, убранство внутреннее делает, пристани, каналы, шлюзы, доки. Дома загородные кругом Парижа его работы видели здесь» [9, с. 144]. В этой характеристике ничего не говорится о его умении в фортификации и строительстве городов, что странно для выбора «главного архитектора» Петербурга. Пётр I разрешил принять Леблона на русскую службу, и 13 ноября 1715 года в Париже с ним был заключён договор, по которому ему сразу была установлена оплата в 
пять тысяч рублей в год. Работавший до него Шлютер получил такую сумму только через годы работы.

Зотов везёт Леблона в Пирмонт для представления Петру I, лечившемуся там на водах. Пётр I провел три дня (!) в беседах с Леблоном и написал Меншикову: «Леблона примите приятно и по контракту довольствуйте, ибо сей мастер из лучших и прямо диковинкою есть, как я в короткое время мог рассмотреть. К тому же не ленив, добрый и умный человек, также кредит имеет великий в мастеровых во Франции и кого надобно, через него достать можем» [8, с. 115]. Чем Леблон удивил Петра I? Видимо, разговор шёл о строительстве Санкт-Петербурга, для чего и был нанят Леблон. Он высказал какие-то новые идеи Петру I, так его поразившие, иначе не получил бы определение «мастера-диковинки».

В Петербурге в это время работает много иностранных архитекторов. Доменико Трезини с 1706 года ведёт работы по строительству каменной Петропавловской крепости [2], в 1710 году им начата постройка Александро-Невского монастыря, в 1711 году он осуществил достройку Летнего дворца Петра I, в 1712 году начал проектирование Петропавловского собора, в 1714 году разработал проекты типовых домов для «Больших протоков». 0н уже десять лет работает в Петербурге, знаком с Петром I. Почему не он назначен «генерал-архитектором»? В 1715 году из Франции приехал в Петербург архитектор Карл Бартоломео Растрелли, ещё одна кандидатура на должность «генерал-архитектора», но и он не получает этого звания.

Жан Батист Леблон, 37 лет, приехал в Петербург 7 августа 1716 года. Ничем себя не зарекомендовав, он сразу получил звание «генерал-архитектора». Приказом Петра I ему были подчинены все архитекторы: «все дела, которые вновь начинать будут, чтобы без подписи его на чертежах не строили» [8]. Почему руководителем архитектурных работ назначается только что приехавший Леблон? Уже 10 августа приказ объявлен архитекторам, что вызвало их всеобщее недовольство. Меншикову пришлось лично уговаривать Растрелли, о чём он извещал Петра I: «...и с него Леблонда воли снимать не будем» [8].

С подчинёнными ему архитекторами Леблон не нашёл общего языка, не смог выстроить не только дружеских, но и творческих отношений. Он постоянно придирается, требует вносить изменения в проекты. Ряд мастеров, приехавших с ним, уезжают на родину. Почему он проявлял такое пренебрежение к работе коллег? Но критики архитекторов Леблону мало, он хочет быть, единственным архитектором Петра I и в 1717 году пишет ему записку: «не надо иметь столь много архитекторов. Король Франции много знатных зданий строит, однако же имеет одного архитектора» [8].

Леблон вводит требование: все проектные работы должны проводиться только в его мастерской, «имевшей довольное число рисовальщиков» [9, с. 148]. «"Генерал-архитектор" все строения ругает... обещая всему сделать собственные проекты», пишет Меншиков Петру I [9, с. 148]. Однако его вмешательство даёт мало результатов. К приезду Леблона в
Петергофе уже выстроены дворец и Монплезир, его предложения сводятся к улучшению фасада дворца, по его проекту отделаны дубом дворцовый кабинет и интерьер Монплезира. Идеи Леблона по изменению планировки Петергофского парка не утверждены Петром, отвергнута кровля Грота в Летнем саду: «у грота в Летнем доме кровле по Леблону не быть, а делать как у Маттарнови» [9, с. 154]. Не осуществлена планировка Летнего сада и парка Екатерингофа, при строительстве Стрельнинского парка в проект Леблона были внесены многочисленные изменения.

Леблон конфликтует не только с подчинёнными ему архитекторами, он ссорится с генерал-губернатором Петербурга князем Меншиковым. Леблон учреждает канцелярию городовых дел и требует от Меншикова приезжать туда по определённым Леблоном дням. Неужели Леблон, работая при французском королевском дворе, не понимал правил взаимоотношений наёмного работника с представителями высшей власти? Жизнь Леблона в Петербурге полна загадок. Однажды он даже «подвергся нападению наёмных убийц» [8].

Леблон скоропостижно умирает зимой 1719 года, даты его смерти разнятся, причина не ясна. Чем же определены взаимоотношения императора России Петра I и одного из многих наёмных иностранных архитекторов, приглашённых в Россию? В чём заключалась заинтересованность Петра I именно в Леблоне?

Попробуем взглянуть на историю Леблона в Петербурге с другой точки зрения. Его проект плана Санкт-Петербурга показал принципы нового градостроительного мышления, не просто регулятивного, но ставящего идеальный замысел города выше любых препятствий. Этот проект - символ воли и власти человека над природой, и человек этот - император России Пётр I. Леблон предложил ему новое понимание столичного города, вероятно, это и восхитило императора - возможностью воплощения новых идей в планировке Санкт-Петербурга. Кто был носителем этих идей и знаний? Возможный ответ - члены масонских лож, древних объединений «вольных каменщиков», строивших по всей Европе готические соборы, замки, крепости и дворцы. «Вольные»-так как они не принадлежали господину, а свободно работали по заказам в разных странах. Мог ли Леблон быть членом такой строительный ложи? Мог ли Пётр I входить в одну из масонских лож? Попробуем взглянуть на историю работы Леблона и предложенный им план Санкт-Петербурга с этой спорной, но вероятной точки зрения. Для этого необходимо совершить экскурс в историю раннего масонства $[4 ; 7]$.

Масонские ложи насчитывают два этапа развития: «нерегулярное» и «регулярное» масонство. Масонские ложи «нерегулярного» периода были объединениями профессиональных строителей - гильдиями вольных каменщиков, франк-масонов. «Нерегулярное» масонство, развивалось с X века, первый съезд масонских лож прошёл в Йорке в 926 году. Руководил ложей Марк-мастер, имеющий собственный знак - марку, составленный из его инициалов. Таким знаком 
отмечалась не только постройка, но и каждый камень, обработанный членами ложи (ложа - это рабочее помещение каменщиков). Документирован съезд вольных каменщиков в 1275 году в Страсбурге, на котором были утверждены уставы, символика, правила приёма новичков, унифицированные для всех лож. В 1459 году в Страсбурге вновь состоялся съезд вольных каменщиков, в котором участвовали 19 местных лож. В 1498 году вольности германских франк-масонов были подтверждены императором Максимилианом. В 1564 году в Страсбурге состоялся второй европейский съезд вольных каменщиков, на котором страсбургская ложа получила статус Главенствующей или Великой ложи германских масонов. После завоевания Эльзаса Людовиком XIV страсбургская ложа была лишена в 1731 году имперского титула [4, с. 30]. Аналогичные ложи существовали в Англии и Шотландии, в Лондоне ложа основана около 1620 года. Древнейшие дошедшие до нашего времени документы английских строительных артелей относятся к 1352, 1370 и 1409 годам - это уставы артели, работавшей в Йорке. Ложи соблюдали обязанности гостеприимства и братской помощи, между ними существовала организационная связь. Со второй половины XVI века осуществлялись контакты между английскими, французскими, немецкими, голландскими ложами. В конце XVI века в Шотландии все ложи были подчинены чиновнику, заведовавшему казёнными стройками и получившему титул Верховного Надзирателя или Главного Мастера масонов [4, с. 8]. Эти чиновники были королевскими придворными, что сыграло определяющую роль в привлечении в ложи дворянства.

Во второй половине XV века из профессиональных лож начинают выделяться «ложи-братства», и между ними устанавливаются различия. Цех ведает ремесленными делами, братство - хранители традиций и морали, организаторы взаимопомощи. Для вступления в Братство не требуется обязательно быть цеховым рабочим. Первый документиро-

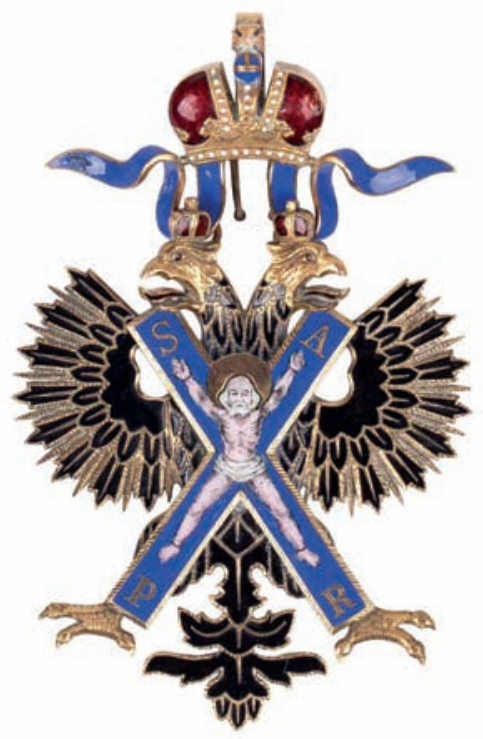

Рис. 1. Знак ордена Андрея Первозванного ванный случай принятия в ложу постороннего лица относится к 3 июня 1600 года: в Эдинбургскую ложу был принят сэр Джон Бозуэл, лорд Очинлекский. С тех пор присутствие в шотландских ложах знати становится обычным, что привело в начале XVII века к образованию особой категории лож, называемых «спекулятивным» масонством, - масонов-теоретиков, носителей моральной теории о духовном строительстве в человеческом обществе.

Из этого краткого обзора истории раннего «оперативного» масонства и масонства «спекулятивного» ясно, что к началу XVII века уже существовала развитая система масонских лож. Членами этих лож были и архитекторы как носители знаний о строительстве и архитектуре. Вполне вероятно, что членом такой ложи являлся и Леблон, а как «королевский архитектор» он мог иметь степень Мастера и, основываясь на ней, требовать подчинения ему всех работавших в Петербурге архитекторов. То, что архитекторы входили в масонские ложи и занимали высокие посты, - исторический факт. Английский архитектор Кристофер Ренн, построивший в Лондоне собор Святого Павла, был главой самой старой и крупной ложи в Англии - ложи Святого Андрея Первозванного [7]. 0собо отметим этот факт, играющий важную роль в дальнейшем.

Пётр I был осведомлён о масонстве. Его ближайшее окружение: Франц Лефорт, Яков Брюс, были членами лож. Во время Великого посольства в Европу 1697-1698 годов Яков Брюс по рекомендации Кристофера Ренна встречался с видным масоном Англии Исааком Ньютоном и организовал встречу с ними Петра I. Был ли Пётр I принят в члены ложи вопрос спорный. Л. Мацих, занимавшийся изучением русского масонства, говорил, что Петра I не приняли в масоны, но он был заинтересован и по возвращении в Россию создал, по выражению Л. Мациха, «прото-масонскую» структуру, выросшую в первую русскую ложу, документально упомянутую в 1731 году [5].

Однако существует версия о вступлении Петра I во время визита в Англию в ложу шотландского обряда. Она основывается на создании им в России ордена Андрея Первозванного, аналогичного по названию английской ложе, возглавляемой Кристофером Ренном. Члены ордена получали орденские знаки в виде звезды и распятия святого Андрея (рис. 1). 0 связи этого ордена с масонством говорит тот факт, что высокие степени масонства были посвящены Андрею Первозванному, цвет ордена - красный. Орденские знаки с изображением распятия святого Андрея приводятся в числе масонских принадлежностей $[4$, с. 83, 108]. «Среди русских масонов существовало предание о том, что первая масонская ложа в России была учреждена Петром Великим, немедленно по его возвращении из первого заграничного путешествия: сам Кристофер Врен (Ренн), знаменитый основатель нового английского масонства, будто бы посвятил его в таинство ордена. Мастером Стула в основанной Петром ложе был Лефорт, Гордон - первым, а сам царь - вторым Надзирателем» $[4,126]$. 
Полагаем, что косвенным подтверждением версии о масонстве Петра I служат его определённые пристрастия в архитектуре. Леблон проектирует интерьеры кабинета Петра I и Монплезира в Петергофе в английском стиле, что странно для французского архитектора. Ясно, что это не его выбор, а решение Петра I - император хочет видеть интерьеры, соответствующие духу братства, в котором состоит. В главном зале Монплезира пол выложен чернобелой плиткой в шахматном порядке, что характерно для зала собраний масонских лож. Цвет фасадов Монплезира красно-белый, что соответствует цветам ложи Андрея Первозванного и высоких степеней масонства. Возможно, эти интерьеры могли служить для заседания российской ложи Андрея Первозванного (рис. 2). В 1724 году Пётр I заказал шведскому архитектору Тессина-младшему проект Андреевской церкви на Стрелке Васильевского острова. При проектировании было поставлено условие: церковь должна напоминать собор Святого Павла в Лондоне, автор которого Кристофер Ренн, был главой масонской ложи Андрея Первозванного. Собор не был построен из-за смерти Петра I. Существующий ныне в Петербурге собор святого Андрея построен в 1764-1780 годы по проекту архитектора А.Ф. Виста (рис. 3 а). Он не похож на собор святого Павла, но имеет необычную для русских храмов архитектуру - все объёмы сильно вытянуты. Цвет фасадов собора - красный. Церковь св. Андрея есть и в Киеве, она имеет схожее архитектурное решение с петербургским собором, но цвет ее фасадов - голубой. В этой цветовой разнице скрыт смысл этих соборов. Красный цвет - цвет масонской ложи, поэтому петербургский собор - это орденский собор ложи св. Андрея. Киевская церковь имеет голубой цвет орденской ленты - это церковь кавалеров ордена святого Андрея, то есть это так называемая кавалерская церковь (рис. 3 б). Но неужели все задания, фасады которых выполнены из красного кирпича, являются масонскими? Вовсе нет, это просто цвет материала. Но и Монплезир, и Андреевские соборы оштукатурены, выбор цвета для покраски штукатурного фасада есть целенаправленный акт: он может быть любой, но выбраны цвета, имеющие символическое значение в масонстве и в ордене святого Андрея.

С точки зрения версии о членстве Леблона и Петра I в масонских ложах история работы Леблона в СанктПетербурге может быть представлена следующим образом. Иван Исаевич Лефорт, также как и его знаменитый дядя, вероятно состоял членом масонской ложи. Он прибыл в Париж в сентябре 1715 года, когда Леблон остался без работы. Лефорт оказывает ему помощь и рекомендует «брата» Леблона для работы в России. Зотов везёт его в Пирмонт для представления Петру I, что вряд ли было возможно без приглашения. Предположим, что Пётр I осведомлён о масонстве Леблона. Исходя из этого, становятся понятным их трёхдневное общение: это встреча двух «братьев» - членов тайного общества. Леблон предлагает положить в основу строящегося Санкт-Петербурга масонскую символику, выражающую статус императора России. Столица России должна стать городом-символом, а не просто вариантом Амстердама, столь любимого Петром I. Пётр I принимает эту идею, почему и появляется определение Леблона как «архитектора-диковинки», ему присваивается звание «генерал-архитектора» и поручается подготовка нового плана города. Прибыв в Петербург, он начинает реализацию этого плана, не посвящая в него прочих архитекторов, вносит поправки в проекты, не объясняя смысла своих требований, что ведёт к конфликтам. В результате Леблон сосредотачивает проектирование в своей мастерской и пишет Петру I о необходимости «иметь только одного архитектора», что нужно для создания единого архитектурного ансамбля города-символа. Конфликты с генерал-губернатором Меншиковым имеют ту же основу: его представления об архитектуре города отвергались и не учитывались. В этой версии переплетаются разные мотивы: государственные интересы и желание Петра I построить небывалую столицу, идеи «спекулятивного» масонства XVII - начала XVIII века, интересы властной верхушки России и Санкт-Петербурга, градостроительные амбиции архитектора.

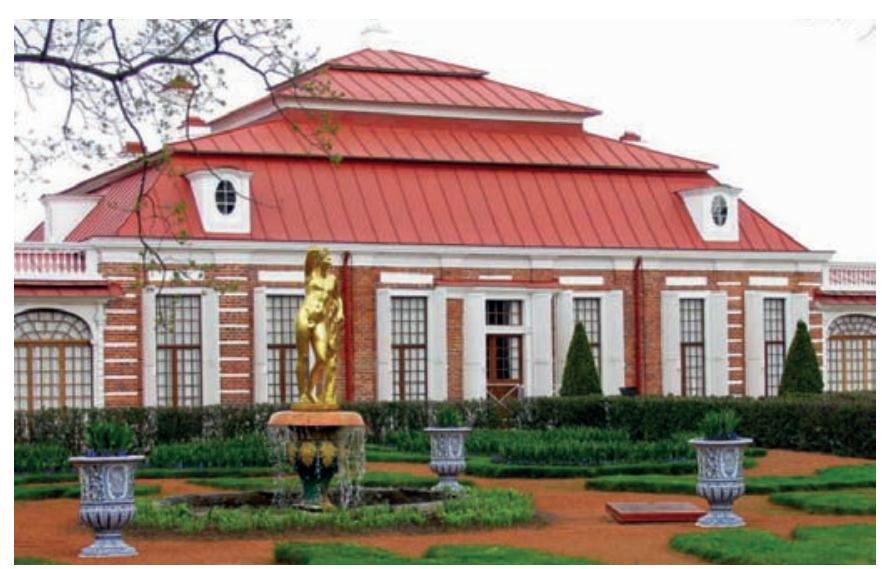

a)

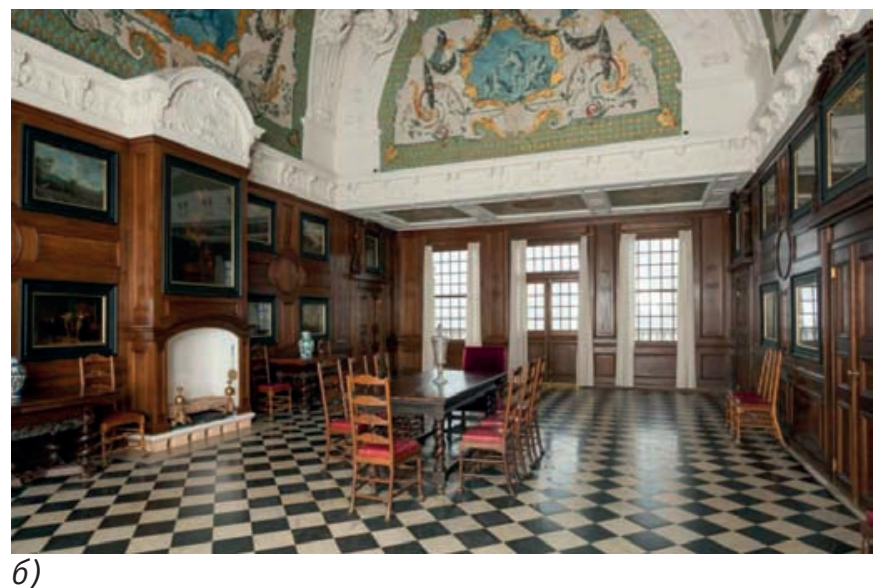

Pис. 2. Монплезир: а) фасад главного корпуса; б) интерьер главного зала (фото из открытых источников сети Интернет) 


\section{Санкт-Петербург - город-символ}

Символы имеют важное значение в жизни человечества. По словам М. Альбедиль «...символы - сгустки смысла, в которых сходится множество глубоких значений, порой не-

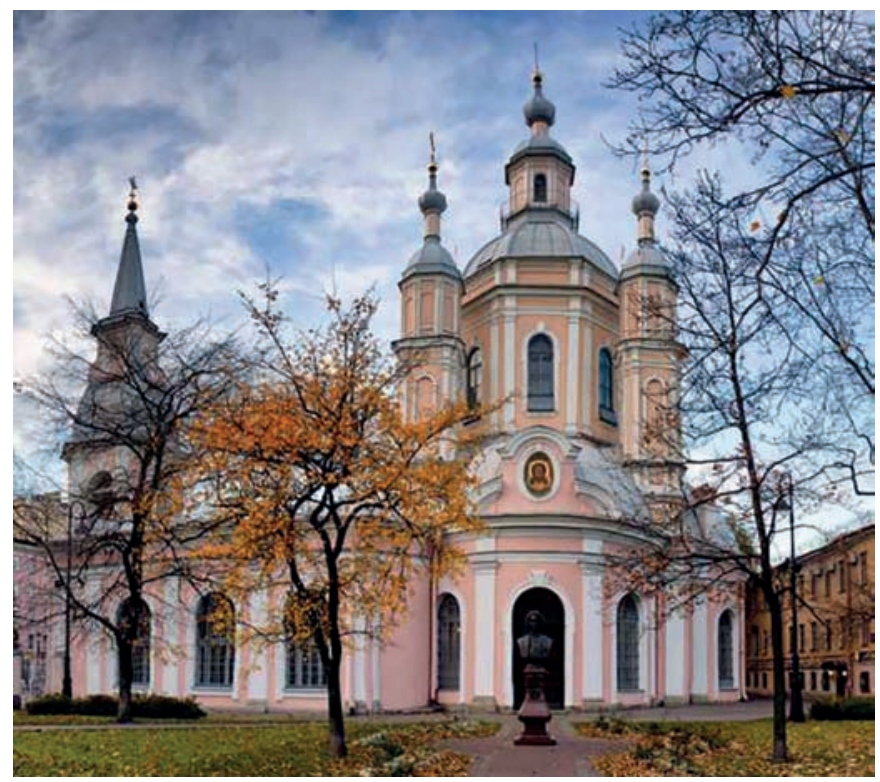

a)

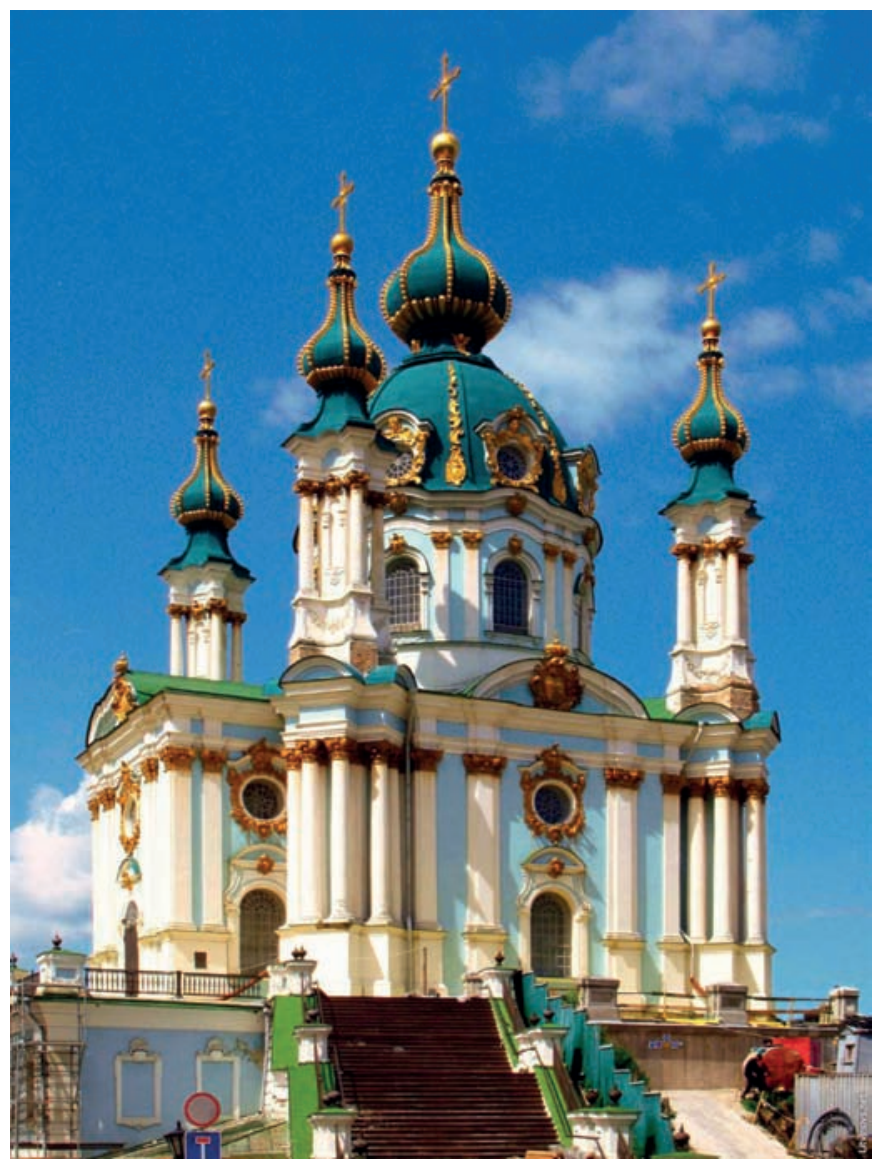

б)

Рис. 3. Цветовое решение Андреевских храмов (фото из открытых источников сети Интернет): а) Андреевский собор. (анкт-Петербург; б) Андреевская церковь. Киев ведомых, но интимно постигаемых и потому внятных» [9, с. 9]. Август Шлегель называл символ «знаком бесконечности в конечном» [9, с. 5]. Символы составляют первооснову культуры, поэтому архитектура и градостроительство не могут обойтись без их использования и выражения своими средствами.

Каким мог быть Петербург как символ, основанный на идеях и символике «спекулятивного» масонства XVIII века? Какие масонские символы можно «прочесть» на плане СанктПетербурга? Леблон создал геометрически правильную форму плана в виде эллипса. Он работает как «Мастер-геометр», что характерно для работ архитекторов-масонов, реализующих «Высший замысел» по переустройству мира (рис. 4). Но почему выбрана именно такая форма? Этому можно дать несколько объяснений. С планировочной точки зрения, эллиптическая форма плана позволяла Леблону охватить застройкой три острова, но территория Васильевского острова оставалась главенствующей в городском плане. Интересную версию высказал член-корреспондент РААСН А.В. Долгов: он отметил сходство форм плана Петербурга и римского Колизея. Форма плана новой столицы России отождествляется с самым известным объектом Рима, чем устанавливалась духовная связь и подчёркивалась идея русского православия - «Москва есть третий Рим», в которой Москва понимается как Московское царство.

Овальный план города окружают треугольные по форме бастионы крепости, которые образуют многолучевую звезду. Бастионов - тридцать три, хотя могло быть любое количество. Число тридцать три соответствует высшей степи посвящения в системе масонства старого шотландского обряда. В ней титул 33-ей степени - Верховный Генеральный Инспектор - как нельзя лучше соответствует императору России Петру I [6, с. 48]. Такое числовое совпадение, по нашему мнению, не может быть случайным, а показывает статус Петра I в масонской ложе. У «ожерелья бастионов» есть особенность: в восточной части города у Петропавловской крепости выделяются

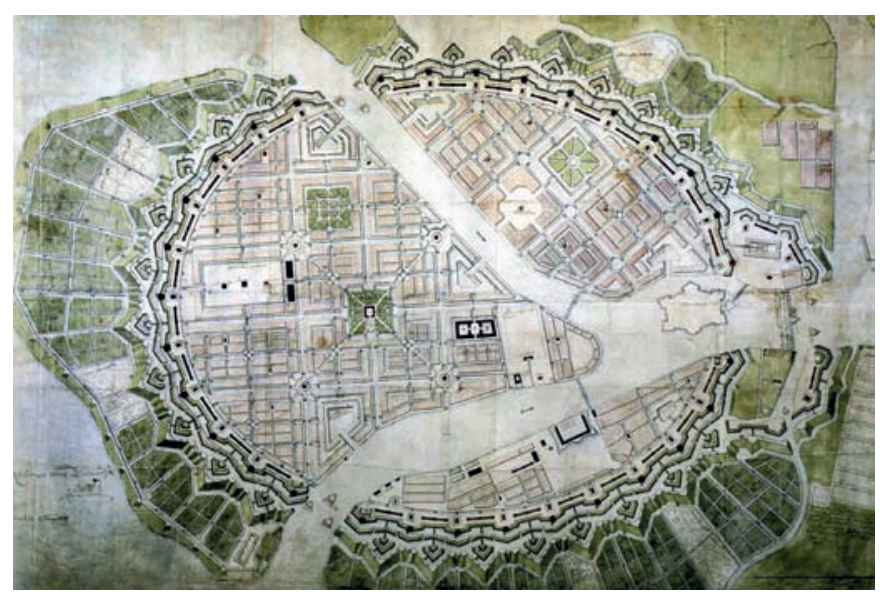

Рис. 4. План Санкт-Петербурга. Архитектор Леблон. 1717 год (изображение из открытых источников сети Интернет) 
семь бастионов, отличающихся от прочих своими размерами и формой. Многолучевая форма плана города похожа на форму наградного медальона Петра I, который был предшественником первых русских орденов. Медальон венчался императорской короной и, возможно, семь бастионов нестандартной формы символизируют корону. Таким образом, происходит отождествление этого медальона и плана города, а город в таком символическом контексте становится наградой Петра I для всей России (рис. 5)

Символика масонства включает в себя множество символов как общего характера, относящихся к его идеям, так и соответствующих определённым степеням масонского посвящения (рис. 6). Это даёт множество вариантов для выражения этих символов в планировке города средствами градостроительства.

Этому служили все элементы плана Петербурга, как планировочные - искусственные, так и естественные природные элементы ландшафта. Наиболее важные и часто употребляемые в архитектуре символы нашли своё отражение в плане города.

- Пирамида с отсечённой вершиной в виде Лучезарной Дельты - самый сложный и неоднозначный по толкованию символ. Во-первых, это символ строительства мира под наблюдением Всевидящего Ока Великого Архитектора Вселенной. Незавершённость пирамиды показывает, что «строительство мира» не закончено и вряд ли когда-нибудь будет завершено. Во-вторых - символ главенства «вершины» над «целым», то есть власти над обществом. Пирамида часто встречается в масонской архитектуре в виде храма или гробницы, что связывается с архитектурой Египта и должно подчёркивать древность масонского учения. Символом Пирамиды служит предлагаемая к застройке часть территории Васильевского острова, имеющая треугольную форму.

Часть этой Пирамиды в плане отделена огромной усадьбой князя Меньшикова. Поэтому застройка Стрелки не может быть соединена с остальной застройкой Васильевского острова вершина Пирамиды будет оставаться «отсечённой», создав форму «отсечённой Дельты».

- Лучезарная дельта - Всевидящее Око - представляет собой треугольник, в который оно вписано, с расходящимися во все стороны лучами. Это символ Великого Архитектора Вселенной, наблюдающего за трудами масонов. В другой трактовке - символ мудрости и истины. Он часто применяется храмовой архитектуре, помещаясь в треугольнике фронтонов зданий, в иконостасах и оформлении интерьеров церквей. Есть он и в плане Санкт-Петербурга, образованный застройкой стрелки Васильевского острова: она имеет овальную форму «глаза» в центре которой незастроенная территория символически означающая Всевидящее Око. Она создана явно специально: окружённая кварталами застройки, эта свободная территория не имеет никакого функционального назначения. Эта символическая форма планировки сохра- нялась в застройке Стрелки длительное время, она хорошо видна на девяти исторических планах города с 1776 по 1887 год и исчезает в плане 1903 года, на котором вся территория застраивается малозначительными объектами.

- Циркуль и наугольник- инструменты архитекторов и строителей. Это наиболее распространённая символическая эмблема масонов; она часто встречается в декоре зданий. Трактуется как первооснова существования: циркуль небесный свод (небесный мир), что выражается через форму круга, создающуюся циркулем. Наугольник - земля (земной мир), что объясняется через форму креста - пересечение двух прямых, символизирующих землю [10]. В

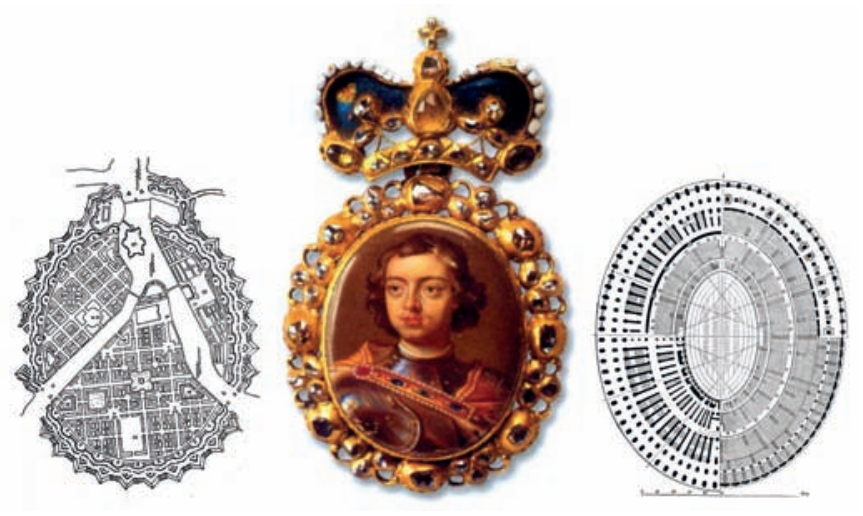

Рис. 5. Сравнение форм плана Санкт-Петербурга, наградного медальона Петра и Колизея (изображения из открытых источников сети Интернет)

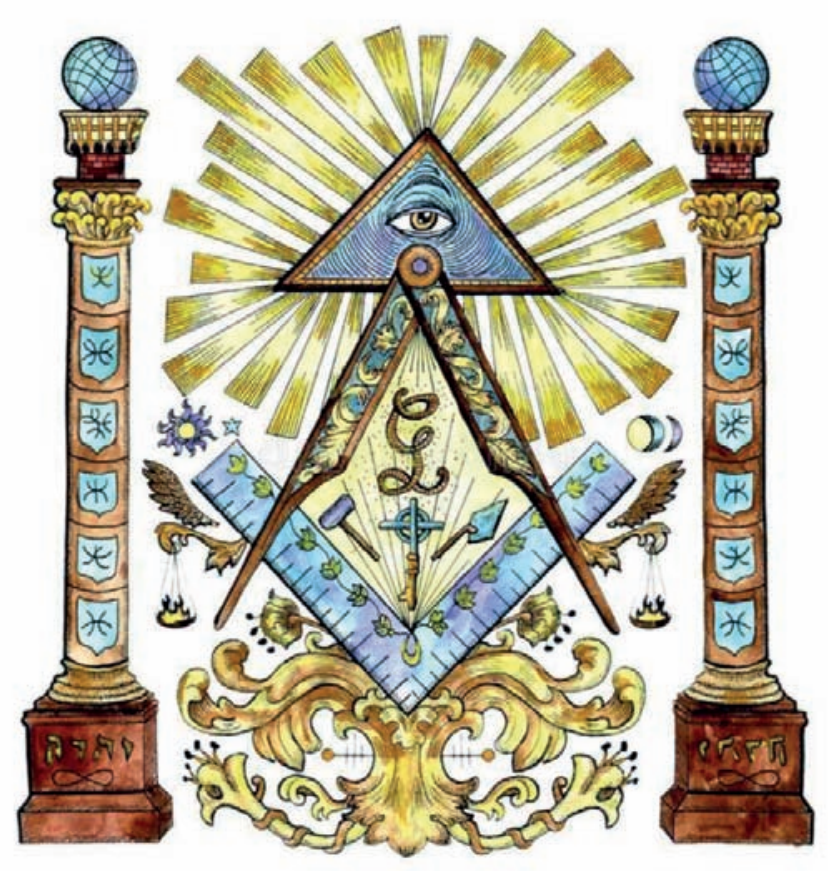

Рис. 6. Символы масонства. Лучезарная дельта, Циркуль, Наугольник, Мастерок, Молоток, колонны Боаз и Яхин (изображение из открытых источников сети Интернет) 
масонстве часто трактуются как символы обучения мастерству строителя в прямом и духовном значениях. В плане Санкт-Петербурга Циркуль выражен Невой, разделяющейся у Стрелки Васильевского острова на два рукава, образуя тем самым «ножки» Циркуля. Символически «ручкой» Циркуля служит Петропавловская крепость, его «дуге» соответствуют два моста через рукава Невы. По нашему мнению, именно для символического воплощения формы Циркуля Леблону потребовалось сдвинуть на плане город выше по течению Невы: при такой сдвижке оба рукава реки вошли в черту

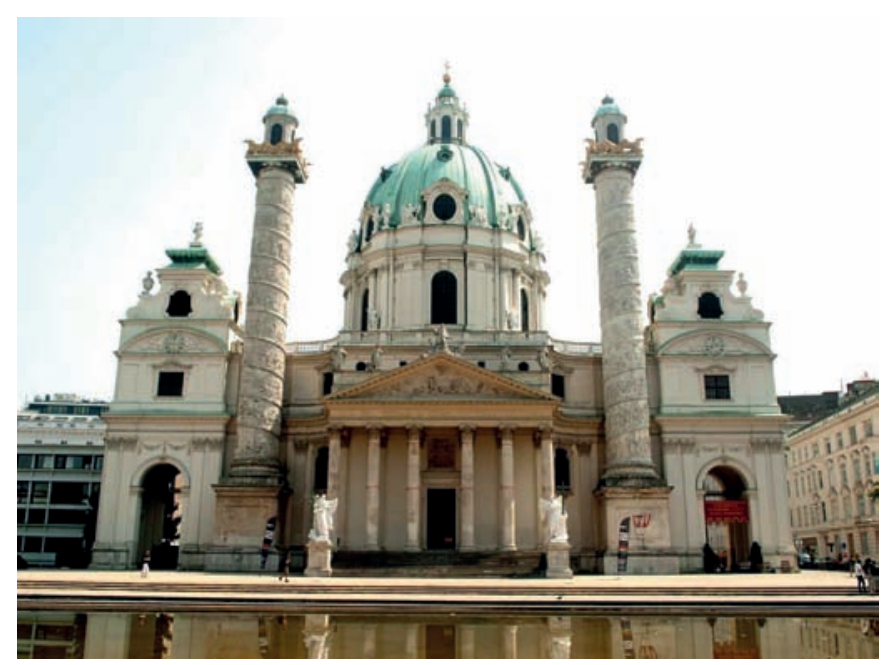

Рис. 7. Церковь Карлскирхе. Вена. 1717-1736 годы (фото из открытых источников сети Интернет)

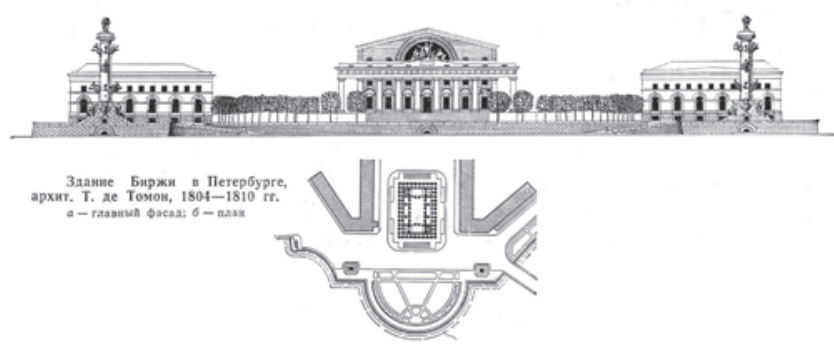

Рис. 8. Здание биржи. Санкт-Петербург. Архитектор Тома де Томон. 1804-1810 годы (изображение из открытых источников сети Интернет)

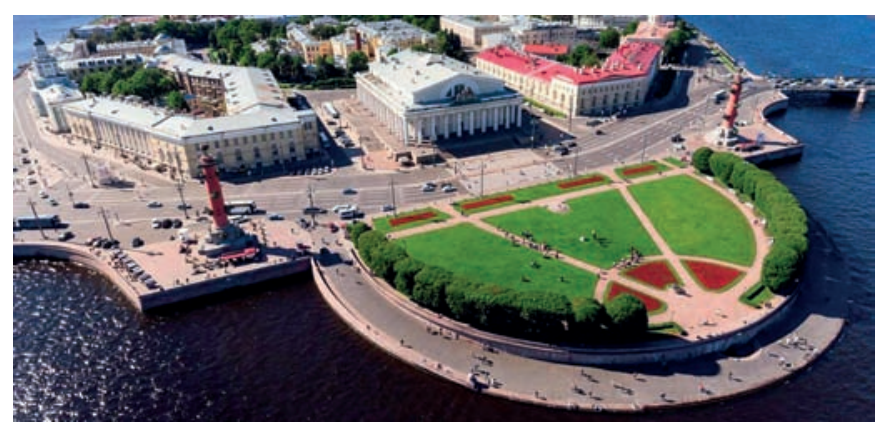

Рис. 9. Благоустройство площади биржи. Символическое изображение циркуля (фото из открытых источников сети Интернет) города. В планировке нет одного Наугольника, но существует большое количество малых планировочных форм, соответствующих этому символу.

- Крест Андрея Первозванного ясно прочитывается в планировке Васильевского острова. Он не мог не появиться, так как Пётр I создал масонскую ложу его имени. Этот крест образован двумя диагоналями между круглыми площадями с храмами различных конфессий. В центре пересечения диагоналей находится дворец Петра I - знак роли Петра в ордене.

- Две колонны, называемые Боаз и Яхин, - символы древнего Храма Соломона. Видимо, имеют происхождение от древнеегипетских обелисков, парно стоящих у входов в храмы. Значение колонны Яхин - «да утвердит Он», колонны Боаз - «в Нём Сила». Часто используется в архитектуре, например, в венской церкви Карлскирхе (1716-1737) (рис. 7). Парные колонны присутствуют в интерьерах масонских лож и храмов. Леблон не показал эти два символа в планировке Санкт-Петербурга, они появились позднее в XIX веке, когда архитектор Тома де Томон спроектировал в духе масонской символики здание Биржи и две ростральные колонны на Стрелке Васильевского острова (1805-1810) (рис. 8). По словам С. Кавтарадзе, Томон «...не скрывал свою принадлежность к ложе» [1, с. 183]. Томон сам говорил о значении масонских символов: «Циркуль изображает небесный свод, а Угольник - землю. Земля -место, где человек выполняет свою работу, а небо символически связано с местом, где чертит свой план Великий Строитель Вселенной» [1, с. 185]. Биржа служит образом символического Храма Соломона, ростральные колонны - образом колонн Яхин и Боаз. Их высота составляет 32 метра, что соответствует высшей степени посвящения во французском масонстве, к которому принадлежал Тома де Томон. Титул этой степени посвящения называется Высокий Хранитель Королевской Тайны. Томон изобразил Циркуль в плане благоустройства площади, он и сегодня присутствует на территории сквера на самом мысу Стрелки в виде двух «разбегающихся» дорожек, объединённых третьей в виде дуги. Таким образом, Стрелка - место Небесного мира, самая сакральная точка Петербурга (рис. 9). Храм Соломона в понимании масонов - символ построения совершенного общества, духовного самосовершенствования. В застройке Стрелки позади здания Храма Тома де Томон создал полукруглую площадь на том самом месте, где в плане Петербурга Леблон изобразил Всевидящее Око в Лучезарной Дельте.

Обнаруженные нами масонские символы в планировке Санкт-Петербурга, созданной Леблоном, позволяют говорить, что весь план города выражает роль и статус Петра I в масонской ложе. Город-символ Леблона может быть «прочитан» следующим образом: «Город Санкт-Петербург, столица Третьего Рима - православной России; коронный императорский город, мастера 33 степени посвящения масонской ложи старого шотландского обряда Андрея Первозванного, 
Верховного Генерального Инспектора масонов - императора Петра I» (рис. 10). 06 этом говорит его желание построить на Васильевском острове храм Святого Андрея, похожий на собор Святого Павла в Лондоне.

Непонимание сакрального значения символов, скрытых в архитектурных планах города, ведёт к их утрате, потере смысла планировки и замене его узким пониманием функциональности использования территорий. Реализация плана Леблона могла привести к созданию уникального по своему смыслу города.

$$
\text { *** }
$$

Версия о масонской символике плана Петербурга, разработанного Леблоном, позволяет считать этот проект не только первым регулярным планом города в России, но и первым проектом, основанным на символизме градостроительных форм. Он знаменовал приход в российское градостроительство новых принципов мышления, благодаря которым в проектировании появились образная и символическая составляющие. Это означало важный шаг к восприятию градостроительства как искусства, способного создать целостное архитектурно-градостроительное произведение. Город начал восприниматься как объект искусства, в ходе создания которого для достижения художественного эффекта можно преодолеть любые ограничения, а не только подстраиваться под них, решая утилитарные задачи. Леблон показал возможности такого художественного проектирования, которые к концу XVIII века стали широко применятся в отечественном градостроительстве, пусть и на иной стилевой основе.

Утопические идеи «спекулятивного масонства», которое ставило целью создание идеального общества, существенно изменили теорию и практику градостроительства. Смысл этого «сакрального градостроительства» прекрасно выразил С. Кавтарадзе: «Идея о Боге, как о Высшем архитекторе, буквально до небес поднимает и статус самого зодчества. Архитектура преодолевает собственные пределы... Своей мифологией масоны отметили тенденцию, развивавшуюся со времён Ренессанса. Отчасти благодаря им деятельность зодчего вновь стала подразумевать не только решение утилитарных проблем, но и гармонизацию самой Вселенной, пусть поначалу в масштабах храмовых комплексов, дворцовых ансамблей или градостроительных планов» [1, с. 185].

Архитектор-творец, создающий в градостроительном масштабе «идеальный мир» на Земле, по смыслу связанный с «идеальным небесным миром», становится главным действующим лицом в градостроительном процессе. В этой попытке выразить сакральные смыслы языком градостроительства заложено стремление реализовать на практике, в земной реальности, представления зодчего об идеальном мироустройстве. В «идеальном городе», пришедшем к нам из «идеального мира», по мысли его создателя, должна наи-

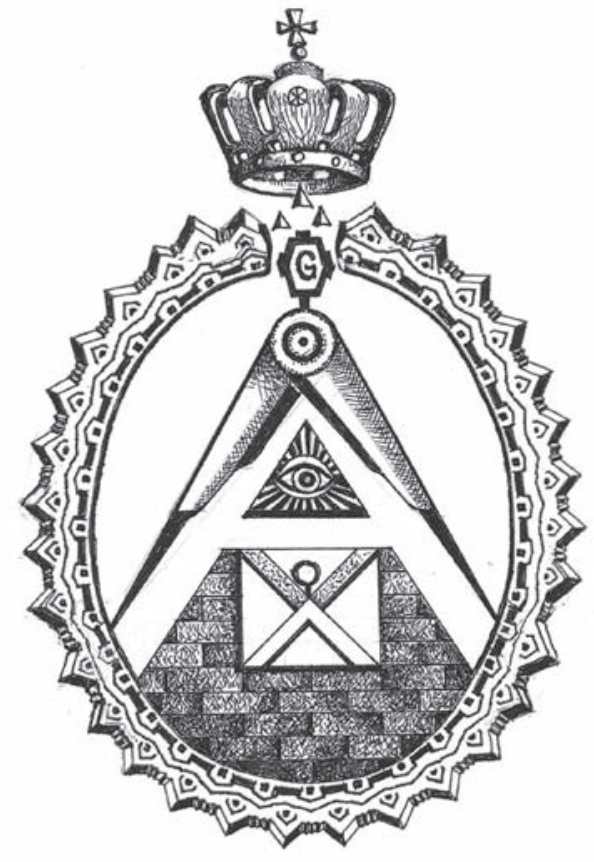

Рис. 10. Эмблема Санкт-Петербурга - города-символа (изображение из открытых источников сети Интернет)

лучшим образом строиться жизнь реальных людей. Леблон принёс в Россию новый уровень градостроительного мышления, но его идеи не получили практическое воплощение, так как значительно опередили своё время.

\section{Лuтература}

1. Кавтарадзе, С. Анатомия архитектуры. Семь книг о логике, форме и смысле / С. Кавтарадзе; 3-е издание. - М. : Издательский дом Высшей школы экономики, 2017. - 472 с.

2. История Петропавловской крепости / Комитет по культуре Санкт-Петербурга. Государственный музей истории Санкт-Петербурга. - СПб, 2017. - 20 с.

3. Леврон, Ж. Лучшие произведения французских архитекторов прошлого / Ж. Леврон. - М. : Стройиздат, 1986. - 170 с.

4. Масонство в его прошлом и настоящем : в 2 томах. Том 1 / Под ред. С.П. Мельгунова, и Н.П. Сидорова. - М. : Задруги, 1914; Издание К.Ф. Некрасова, ИКПА, 1991 (репринтное издание). - 255 с.

5. Мацих, Л. Беседы о Петре I [Электронный ресурс]. - Режим доступа: https://bR-plus.net (дата обращения 09.09.2020).

6. Папюс, А. Генезис и развитие масонских символов - Репринтное воспроизведение издания 1911 г. - Рига : Издательско-библиографическое агентство «Моя библиотека», 1991. - 119 с.

7. Рыбалка, А. Тайны русских соборов / А. Рыбалка, А. Синельников. - М. : ЭКСМ0, 2008. - 320 с.

8. Русская архитектура первой половины XVIII века. Исследования и материалы / Под ред. академика И.Э. Грабаря. 
- М. : Государственное издательство литературы по строительству и архитектуре, 1954. - 414 с.

9. Каширина, Т. Символы. Знаки / Т. Каширина, Т. Евсеева. - М. : Мир энциклопедий. Аванта+, 2007. - 184 с.

10. Голан, А. Миф и символ / А. Голан. - М. : Руслит, 1993. -375 c.

\section{References}

1. Kavtaradze S. Anatomiya arkhitektury. Sem' knig o logike, forme i smysle [Anatomy of architecture. Seven books on logic, shape and meaning]. Moscow, Publishing House of the Higher School of Economics Publ., 2017, 472 p.

2. Istoriya Petropavlovskoi kreposti [History of the Peter and Paul Fortress]. Saint Petersburg, 2017, 20 p.

3. Levron Zh. Luchshie proizvedeniya frantsuzskikh arkhitektorov proshlogo [The best works of French architects of the past]. Moscow, Stroiizdat Publ., 1986, 170 p.

4. Mel'chukova S.P., Sidorova N.P. (eds). Masonstvo v ego proshlom i nastoyashchem. V 2 tomah T. 1. [Freemasonry in its past and present. In 2 volumes. Vol. 1.]. Moscow, Zadrugi Publ., 1914; Moscow, K.F. Nekrasov, IKPA Publ., 1991 (reprinted edition), $255 \mathrm{p}$.

5. Matsikh L. Besedy o Petre I [Conversations about Peter I]. Access mode: https://bR-plus.net (accessed 09.09.2020).

6. Papyus A. Genezis i razvitie masonskikh simvolov [Papyus. Genezis i razvitie masonskikh simvolov], Reprintnoe vosproizvedenie izdaniya $1911 \mathrm{~g}$. Riga, Publishing and bibliographic agency "Mylibrary" Publ., 1991, 119 p.

7. Rybalka A., Sinel'nikov A. Tainy russkikh soborov [Secrets of Russian cathedrals]. Moscow, EKSM0 Publ., 2008, 320 p.

8. Akademik I.E. Grabar' (ed.). Russkaya arkhitektura pervoi poloviny XVIII veka. Issledovaniya i materialy [Russian architecture of the first half of the 18th century. Research and materials]. Moscow, 1954, 414 p.

9. Kashirina T., Evseeva T. Simvoly. Znaki [Symbols. Signs]. Moscow, World of Encyclopedias, Avanta+ Publ., 2007, 184 p.

10. Golan A. Mif i simvol [Myth and Symbol]. Moscow, Ruslit Publ., 1993, 375 p.

Мазаев Григорий Васильевич (Екатеринбург). Кандидат архитектуры, профессор, академик РААСН. Главный градостроитель института «УралНИИпроект» (филиал ФГБУ «ЦНИИП Минстроя России») (620075, Екатеринбург, просп. Ленина, 50а. УралНИИпроект). Эл.почта: mail@uniip.ru.

Mazaev Grigory V. (Yekaterinburg). Candidate of Architecture, Academician of RAACS. Chief Urban Planner at the UralNIIproekt (50a Lenin ave., Yekaterinburg, 620075. UralNIIproekt), branch of the Central Institute for Research and Design of the Ministry of Construction and Housing and Communal Services of the Russian Federation (TsNIIP). E-mail: mail@uniip.ru. 